\title{
Embodied Disagreements
}

\author{
Anna Mudde
}

\begin{abstract}
Metaphysics is, first of all, not a system; one does not "do" metaphysics as one "does" mathematics or physics. In reality, "to do" metaphysics is "to be" metaphysical; it is to realize oneself in the metaphysical attitude, which consists in positing oneself in one's totality before the totality of the world. (Beauvoir 271)

“... You know, I don't know what goes through people's minds,"... "But my question is this: if he had been clean shaven, if he had been well-dressed, if he had been nonaboriginal and he had come up to them and said, 'My friend just went under in the water,' would they have believed him then?" (Lani Elliott)
\end{abstract}

In one of Simone de Beauvoir's few discussions of metaphysics, in a defense of the philosophical role of literature, she argues for a distinction between the theoretical practices of metaphysics and the situated, embodied, concrete metaphysical experiences that comprise much of our lives. ${ }^{1}$ She compares this distinction to the one evinced in psychology.

... people know well that psychology is not, first of all, a special discipline foreign to life; every human experience has a particular psychological dimension; and while the theoretician draws out and systematizes these significations on an abstract plane, the novelist evokes them in their concrete singularity... It is suitable to conceive of the relations of the novel and metaphysics in an analogous manner. (271)

There is, in "every human event," a "metaphysical signification" that exceeds "its psychological and social elements ... Through his joys, sorrows, resignations, revolts, fears, and hopes, each man realizes a certain metaphysical situation that defines him far more essentially than any of his psychological aptitudes" (271). The usual philosophical practice of

${ }^{1}$ I follow Beauvoir in not naming this the phenomenological terrain, though I take Beauvoir to be an existential-phenomenological thinker. 
metaphysics strives to make this explicit, usually in "more or less systematized," "abstract language," thus pretending that metaphysical experience is something "timeless and objective" (271) - a "special discipline foreign to life." Beauvoir insists there is another way to make explicit what is always already implicit in metaphysical experience: we can draw on lived experience as such, and describe it in concrete, situated terms, as many novelists do. We can, in other words, attend to the minutiae of what it is like to "be here," and to what it is to embody "joys, sorrows, resignations, revolts, fears, and hopes" in response to the world.

In what follows, I dwell not on Beauvoir's point about literature, but on her insight about the lived quality of metaphysics. Taking up the idea that to do theoretical metaphysics requires as a precondition that human beings embody metaphysical experience as a matter of their situated "Being-in-the-world" (271), my interest is in the ways that our embodied judgements, actions, behaviours, and ways of making-sense express the moments of lived, often implicit, metaphysics. I gesture, sometimes point, toward a terrain of experience that I think is often variously articulated, especially in feminist and other contestatory work, but that I think bears more explicit theorization. In this essay, I focus on the ways that individuated, embodied metaphysical experience, structured by learned ways of making sense, is evinced in everyday judgements, expressed in actions, practices, and bodily comportments.

I have in mind the often unrecognized, generally unarticulated, moment or space of experience in which things must be, for us, and in particular ways - as related to/like some things, as distinct from/unlike other things, as not being-with some things and not others - that is, the immediate ontological experiences which give way to the immediate use of language and reasoning, and underlie our capacity to make further judgements and to act. Such experiences thus function to shape the beings we are, in the world and for others: how I respond to what I take there to be and to what I take it to be like conditions the thing I am for others, what it is to have me in the world.

I propose that embodied judgements, inextricable from though not equivalent with one's "joys, sorrows, resignations, revolts, fears, and hopes," evince implicit ontological commitments, ${ }^{2}$ and the activities, thoughts, and beliefs they beget express a metaphysics. That is, I want to suggest that by attending to embodied judgements, expressed in the ways

\footnotetext{
${ }^{2} \mathrm{I}$ am, in a sense, taking inspiration very loosely from Quine's theory of ontological commitment, which in my view misses the really crucial point of thinking about such things. My approach here is more clearly informed by existential-phenomenological thinking, and seeks to track what our implicit metaphysical assumptions/commitments must be in a given experiential situation, without much reference to the sentences we will accept as true.
} 
one experiences/makes sense of and gets around in the world, one can gain access, otherwise unavailable, to one's lived metaphysics. ${ }^{3}$ The set of questions I have in mind, then, is about our "ontological presuppositions" (Butler 214), or underlying, implicit, ontological commitments, the ones we hold that allow us to make certain judgements, and that emerge in our bodily comportments and ways of making sense.

To put the point differently, I am assuming that in addition to viewing metaphysics as an area of philosophical inquiry, a working metaphysics is required for each of us simply to get around in the world. Following feminist epistemological approaches, I am proposing a turn toward the source of theoretical metaphysics as a philosophical subdiscipline and endeavour: embodied judgements. As such I challenge the idea of metaphysics as a theory of the universal, even when it purports to be. And while I do not approach the terrain of contemporary analytic metaphysics, here, favouring instead a narrative instance of everyday metaphysical experience, I read much of that body of works to be of the theoretical sort Beauvoir describes. Following Shannon Sullivan, I take ontology to be neither a discipline of thinking about eternal and unchanging worldly features, nor equivalent only to human conscious experience. It is "constituted instead by the historical, contextual, simultaneously malleable and stable, and only occasionally felt features of situated, located knowers" (32). Starting from the idea that experience is embodied response to a world which is not immediately intelligible, I assume that our most "immediate" perceptions of it are perceptions through sophisticated and implicitly held metaphysical or ontological conceptual apparatuses - sets of categories and classes, ways of individuating, synthesizing, categorizing, and classifying, as Beauvoir puts it, "the totality of the world." In the section below, I draw on a recent incident in the community where I live, reading in it the sort of metaphysical and ontological commitments I propose attending to, and noticing that we have special access to these in situations of ontological disagreement or conflict. After that, I consider a descriptive account of what an ontological disagreement might be like in order to facilitate attendance to them.

\footnotetext{
${ }^{3}$ I am appealing, throughout much of this paper, to retrospective approaches to embodied metaphysics because part of my claim is that as it usually occurs, much of this work is reconstructive and genealogical, prompting thought about what must have been in experience that would have led to particular judgements expressed in actions, practices, and comportments.
} 


\section{What Is It Like To Be You?}

In early September, 2011, Darlyn Johns drowned in Wascana Lake. ${ }^{4}$ It was a Saturday afternoon at the end of a beautiful prairie summer, and there were many people in the park surrounding the lake in front of the provincial legislature building in Regina. What is called a "lake" would be recognizable to most people as a large pond; it is relatively shallow and, at that time of the year, usually warm. Swimming isn't allowed.

Darlyn and some friends had been drinking; it was a warm, sunny Saturday. Darlyn decided to swim. But when he didn't come up to the surface, his distressed friend began asking people in the park to call 911. Eventually, the friend happened upon Lani Elliott, who was taking pictures in front of the legislature. As one news source reported, "a distraught and disheveled aboriginal man approached her. The man said his friend had just died in Wascana Lake, a few steps away, and asked Elliott to call 911.", Elliott told reporters "It was evident to me from his demeanour that he wasn't kidding. He was very upset so I called 911." Here is the rest of the online news piece from The Canadian Press:

Elliott said what happened next was even more disconcerting.

The operator asked the woman when the distraught man had last seen his friend. He told her 30 minutes earlier.

"When I asked him why it took him that long to phone 911, he started crying and he said that no one would help him. He had been asking people in the park to please call 911 or if he could use their phone and no one would help him."

The man said no one believed him.

“...You know, I don't know what goes through people's minds," she said.

"But my question is this: if he had been clean shaven, if he had been well-dressed, if he had been non-aboriginal and he had come up to them and said, 'My friend just went under in the water,' would they have believed him then?

\footnotetext{
${ }^{4}$ Darlyn Johns' obituary can be found here: http://obits.dignitymemorial.com/dignitymemorial/obituary.aspx? $\mathrm{n}=$ Darlyn-Johns\&lc=3861\&pid=153648348\&mid=4815739

5 "Man's pleas to help drowning friend were ignored, woman says." CTV Regina News: http://regina.ctvnews.ca/man-s-pleas-to-help-drowning-friend-were-ignored-womansays-1.696596\#ixzz388fey4sx
} 
"It's too bad that that had to happen and it's too bad that that many people dismissed him based on what he looked like. Yes, he looked like a homeless person. Yes, he was aboriginal. But at the same time he was also a human being and he deserved to be treated with the same amount of dignity and respect that we ourselves would expect." 6

Reading the story of Darlyn Johns' death, and, more pressingly here, his (unnamed) friend's role in that story, I find that I take up the scene in my embodied imagination: I "see" and "feel" the presence of a frantic, "distraught" man, with bodily markers (both real and imagined) of poverty, ethnic "weakness." He asks anyone he encounters for help-not for money, not even for much action. He does not demand people give him their cell phones. He asks them to use their own phones to call 911. I zoom out: Given the amount of time that passed before he found Lani Elliott, no one who he approached even thought to call 911, a few moments later, "of their own accord," perhaps because there was a frantic man in the park. ${ }^{7}$

Elliott asks, perhaps rhetorically, what people could have been thinking, what went through their minds. At once, for me, two conflicting responses emerge. First: Deep understanding. I know and Elliott knows, as many people reading the passage above know, how to account for the experience of Darlyn's friend, for the embodied refusal of assistance. I need not mention how in Canada, racism and colonialism are still lived and form part of what constitutes good judgement and common sense. ${ }^{8}$ Second: Utter incomprehension. How, in the moment one is confronted by desperation (and a fully reasonable request), could the response be refusal? Elliott's question is a common one, and put another way, it might seem to be hopelessly pedestrian: How could they do that?

I want to suggest that this is precisely the philosophical question we might take seriously in this situation, and others like it, and I want to suggest that it is a question about metaphysical experience. To highlight this feature, I reformulate the question this way: What was it like to be the people who would not help? Or, in a more Beauvoirean tone: What is the world (like) for them? How do their situated and situational embodiments underlie their judgements, and how do their "joys, sorrows, resignations,

\footnotetext{
${ }^{6}$ See note 5 .

${ }^{7}$ I think of this response, in particular, remembering sheepishly that I have often asked the police to check on "disheveled" men sleeping in what appear to me to be "strange" places for a nap, behind buildings downtown, or beside dumpsters.

${ }^{8}$ Nor need I mention that Gordon Indian Residential School, the last of its kind to close in Canada in 1996, was only $125 \mathrm{~km}$ from where Darlyn Johns drowned.
} 
revolts, fears, and hopes," express not just their psychological states and traits but their metaphysics?

Opportunities for this sort of reflection arise most clearly, perhaps, in situations of apparent conflict or disagreement. When confronted, or confounded, by another's actions - utterances, motions, practices, habitsespecially when they seem to imply a fundamentally different experience of or judgement about something in the world (or the world itself), I am often led to a similar sort of perplexity about the embodiment of others that Elliott seems to invoke about their thought: "What was it like to be in your body, in that situation, with a world before you, such that you could make that judgement, and make it intelligibly?", "What is the world like for you, such that you can say or do that thing, act that way, think as you do?", "What is it like to be you?"

Beauvoir argues that in good fiction, not only are we exposed to psychological, environmental, and social-historical variety, but that skilled writing also allows readers access to another's metaphysics, his or her concrete, embodied situations, which are inseparable from his or her world, the two forming an experiential whole (271-273). The judgements and actions a character takes can only make sense to readers if the author has sufficiently let us "in" on the character's immediate, embodied experience, or so long as the character does not make any moves that seem to violate his or her metaphysics. How a character sees the world is, in large part, how and who the character is, and in reading them, one has an opportunity to attend to one's own ways of "being here." This is part of the value of (good) literature, Beauvoir argues, and it is the mechanism by which it can both stretch us and make us feel we are not alone.

While in novels, readers often have the advantage of having moved along with the details of a character's lived experiences, or having a narrator to explain them, in non-fictional experience, it makes sense, I think, to ask the questions I outline above. Lani Elliott's question and the disagreement it expresses are, I want to suggest, an opportunity for contestatory thought, which illustrates the potentially transformative role metaphysical attention can play. Such attention is an important feature of feminist, anti-racist, and queer responsibility, but it is also, as Judith Butler suggests, a way of finding both contingent ways of seeing and ways of seeing that are resistant to change (214). Ontological disagreements, I will show, are opportunities for consciousness-raising practices.

\section{What Can Make Sense}

In considering embodied metaphysical differences and how to employ ontological conflicts in fruitful ways, I find it helpful to think with Gaile Pohlhaus, Jr.'s work on understanding others. Pohlhaus highlights 
the ways that African/Black Americans are often asked to "understand" legal provisions that target them for marginalization. She draws on Patricia Williams' work, recounting how, in the 1980s, black people were urged to "understand" the system by which store workers in New York City could decide whom to admit to their stores. To effect such an understanding, Pohlhaus notices, is to temporarily take up a particular way of comporting oneself toward the world - in this case, in a way that makes sense of treating some people illegally by seeing them as inherent threats. Understanding another person (or group of people), Pohlhaus argues, is not simply a matter of holding their claims in mind, or seeing how those claims fit together, their logical structure, and so forth. Understanding another requires us to peer through glasses that allow us to "see" as another does. To understand, then, is not just to take someone's claims seriously as an option; it is to have seen how the world might look, given the ways of seeing someone else employs. In cases where understanding others requires a comportment to something that is harmful, Pohlhaus argues, we can be justified in refusing to understand.

Pohlhaus notices that in experience, to "follow and feel the possible force" of another person's reasoning, to "[attend] to the sense of another's reasoning," (224) is not simply to take up and hold the claims held by another. Rather, to understand another person's reasoning requires a kind of (mental) worldly comportment, since following reasoning is a different sort of enterprise than having reasons. "Following the sense" of another person's claims requires our participation in a movement of those claims (225), not merely holding them in one's mind. She writes:

To follow the sense of a claim is to comport oneself toward the world in particular ways and to participate within the "grammar" which structures the sense of the claim. Our words and language practices situate us in relation to the world and one another not simply by pointing us toward objects waiting to be discovered but rather by providing socially established patterns from which we interact in and with the world. (225)

Reading Pohlhaus' insight another way, to disagree with someone is not simply a matter of failing to hold the same claims as someone else; disagreements - and particularly serious or irreconcilable ones - seem to involve a grounding difference in worldly comportment. When I disagree with you, it is not simply that you and I hold claims in our respective minds that are different from one another's; it is, rather, that what claims we can hold, in a non-voluntarist sense, what can "make sense" to each of us, differs from one another. I noted above that in response to Lani Elliott's question, I at once understood fully the "socially established patterns" from which the park-goers were interacting "in and with the world." Yet, in my embodied imagination, I failed to understand at all how, in the moment of confrontation with desperation, a lack of concern 
came so easily. Thus, on one level, I might be able to refuse to understand what it was like for the people to be in the park on the day Darlyn Johns died. But on another level, I also might never get to that point. I might not be able, really, to understand how police officers in Saskatchewan have so often "allowed" Aboriginal people to freeze out on the prairie while in their custody (see, e.g., Brown). I might not be able, really, to understand how a police officer in Ferguson, Missouri, could see an unarmed teenager with his hands in the air and respond with multiple gunshots. I might not be able to find enough ontological agreement with them to understand them. And that might be morally lucky, for me, but it is not voluntary, and so I cannot refuse to understand. ${ }^{9}$

But what grounds this sort of possibility, such that some claims are intelligible to you, perhaps obvious to you, when they are not intelligible to me? What are we talking about here? It cannot be that there are simply prior claims, understood as uses of wordy language, held in mind, that allow for some sort of sense or reasoning and not another. At some point, it must be that I take my claims to fit the world. And before this, it must be that I experience the world in particular ways, that I am comported towards it such that I experience, notice, attend to, and connect certain things within it, such that I embody situated joy, revulsion, or anxiety. That embodied experience, I want to suggest, is the grounds of our disagreement: you and I often hold different, and sometimes contradictory or incompatible, claims because the claims that will fit, that can fit, the world may be different, one embodied way of being to another. Those claims are ways of making explicit underlying embodied metaphysics and the judgements they make intelligible.

A disagreement, in that case, is not necessarily a failure to understand how your reasoning goes - I may be able to make sense of that; instead, our disagreements may be, and I think are, often grounded on an inability to really see that the other's claims fit the world. Put in different language, what you see in the world I cannot see there, and so the language and "grammar" of our respective claims and their relations differ. More pointedly still, what there is for you, what it is like, what relations it bears, is not what there is for me, what it is like, and what relations it bears. Our primary disagreement is a disagreement of experiences that can be expressed linguistically (or in any other way), at which point we notice the disagreement, or are confronted with it. The disagreement is experiential, despite its becoming apparent in our actions, comportments, gestures, and language. What we may not share are, as María Lugones puts it, "worlds of sense" (e.g., 16, 88). What the world is like for you is not what the world is like for me, and we can see this when

\footnotetext{
${ }^{9}$ To be clear, I do not take this to be a point of disagreement with Pohlhaus.
} 
we disagree. And on the other side, experiences of understanding and connection with others, of agreement, though not of sameness, seem to involve more than simply agreeing about what claims we can make, and how reasoning might go. They involve expressions about what the world is like - such as genuine laughter at the same moment, or how another's body is comported to worldly particulars, that resonate with one's own bodily and embodied experiences of those particulars.

Thus if (when) I disagree with someone else about whether or not the person in front of us warrants fear or help (or both), when he is asking me to call the police, whether our private embodied responses betray the desire to ignore or to recognize the person approaching us, this is not, I want to suggest, primarily a moral or ethical disagreement. Rather, we disagree ontologically, which has inherent and inescapable moral implications. ${ }^{10}$ We may still agree that when someone is in need of help, we ought to help them, and we may even embody that in particular situations. It is only that by paying attention to embodied judgements, any distinction made between lived morality and the ontological becomes difficult to maintain and deeply suspect, and this shifts the inflection of "the moral," among other things, away from the volitional. Alexis Shotwell writes,

... if I think someone has acted in a racist, transphobic, or classist way, and I call on them to change their actions, I am not supposing that all they need is more or different information. Rather, I am calling for a shift in how they move through the world-their inarticulable or unspoken, dynamic, generative framework of understanding. (110; my emphasis)

I want to call these frameworks of understanding working metaphysics or implicit ontologies, and I want to say that in racist, transphobic, and classist action, speech, bodily comportment-like discomfort or revulsion-our bodies betray not only our moral judgements but the metaphysics, the ontological experience, that underlie them.

That there are often metaphysical conflicts or disagreements-and agreements - should not be surprising, if we assume that, like one's knowledge, one's ontological apparatuses and skills are in large part formed by experiences, and that those are both inherently particular to individuals, and the product of similar or common cultural and materialphysical experiences of the world, of common learned ways of interpreting and embodying those experiences. This commonality and

${ }^{10}$ As do, I would argue, all ontological disagreements, including those about time splices, personal identity, realism and anti-realism, parts, properties, universals, and metametaphysical frameworks. 
individuation can also account for simultaneous responses of deep understanding and utter incomprehension at the embodied judgements of others. In the case of Darlyn Johns' death, some people's refusal of help reveals not just the judgements of the people refusing, but their embodied metaphysical experience(s) in that situation, an embodiment that is intimately connected to power, culture, and learned ways of knowing and seeing. It seems clear that, often, different people are using different "maps" of the same territory - on the one hand, we are clearly talking about the same thing, or moving about in the same space; on the other hand, we seem, in philosophical and practical ways, to be dealing with what are very different "things" in the world.

\section{Ontological Skills and Changing What "Is"}

I have been pointing or gesturing toward a terrain that I take to be an extension of feminist, anti-racist, and queer theories and practices. The ways of being that give rise to those theories and practices often emerge from skills developed precisely for answering questions about others as a matter of survival or thriving, to avoid harm, or to ensure calm: How does that bodily creature know in the ways that it does? How must it see (and "see"), sense, feel its way around? What must it experience most palpably in this space, situation, arrangement of the world's furniture? Where do the points of our maps converge? What would it be like to be that knower in that body, and how might that account for his/her actions, beliefs, knowings? How can I "fit" here to minimize harm? What are the points of experiential absence that I can exploit to challenge or make better this situation? Marginalized people, in particular people who have been personally or systematically abused, colonized, or otherwise put in the service of others, often have to be able to "see" a situation as though they were someone else. And they are often, as Pohlhaus argues, right to refuse to understand. The capacity for understanding and refusal are developed epistemic skills, and moral ones. But the capacity to "see" as someone else is also, I am contending, an ontological skill, and a navigational one. In racist social spaces, for instance, knowing what the embodied judgements of the racialized powerful will be, e.g., being able to "see" situations as though one were a racially privileged person, can be an important survival strategy. Yet these are also important questions for privileged knowerdoers because they assume a curiosity in others that is inconducive to what Marilyn Frye calls "the arrogant eye" (e.g., 66, 75), since such questions might only ever arise when I am confronted by someone who is or seems to be unlike me, when my way of making sense is challenged.

Thus, by asking what it is like to be you, I am immediately confronted by and pushed to attend to the reason I am asking, namely, that there is something it is "like" to be me and to be in the world with me. 
These questions can thus express both a curiosity in the self, and an attention to communal ways of making sense and judging. My actions and physical comportment implicitly make claims about "what there is," to which I can attend. What we experience, I am suggesting, is a conflict or disagreement of metaphysics, just not at the level of abstract assertions: something right here, now, is for you and is not for me, and so what principles we judge relevant vary; or what something is (like) for you is not what it is (like) for me; how it is related to other things (and thus, what it is, and what those other things are) is not the same for you as it is for me, and thus what requires doing, or why, will not be a matter of agreement between us. ${ }^{11}$

Yet, as I am suggesting, the "is" of "what there is," for you and for me, and for each of us, is contingent, even when it is unchanging. Our working metaphysics, our maps, are tools: in-process, often situationally specific if trans-situationally salient, and show up as the assumptions and commitments implicit in judgements, which are inherently individuated, but culturally formed and responsive. The questions that I have claimed are important cannot, as I hope is clear, get at an understanding of what it is to be someone else, so much as they can allow one to attend to one's own "being like," one's own making-sense. What they can open is a space for contestatory practices of collective attendance to metaphysical differences and to knowing better with and being better for others.

\footnotetext{
${ }^{11}$ This is one of the reasons why many feminist philosophers of science have urged a diversification of knowers in science: diverse ways of knowing are entwined with diverse capacities to notice, attend to, and make sense of things in the physical world. As such theorists have long recognized, the acceptance or rejection of pieces of scientific knowledge or of particular scientific theories relies in large part on the metaphysical commitments held by members of the scientific community. For perennially helpful collections attending to this line of thought, see Alcoff and Potter, Harding and Hintikka.
} 


\section{Works Cited}

"Man's pleas to help drowning friend were ignored, woman says." CTV Regina News. 13 Sept. 2011. Web. 28 Aug. 2014.

ALCOFF, Linda, and Elizabeth POTTER, eds. Feminist Epistemologies. New York: Routledge, 1993.

BEAUVOIR, Simone de. "Literature and Metaphysics," translated by Margaret A. Simons. Simone de Beauvoir: Philosophical Writings. Ed. Margaret A. Simons, Chicago: University of Illinois Press, 2004. 261-277.

BROWN, DeNeen L. "Left for dead in a Saskatchewan winter." The Washington Post. 22 Nov. 2003. Archived on MSNBC Online Sep 15, 2005. Web. Aug. 29, 2014

BUTLER, Judith. Undoing Gender. Routledge: New York, 2004.

FRYE, Marilyn. "In and Out of Harm's Way: Arrogance and Love." The Politics of Reality: Essays in Feminist Theory. Berkeley, CA: The Crossing Press, 1983. 52-83.

HARDING, Sandra, and Merrill B. HINTIKKA, eds. Discovering Reality: Feminist Perspectives on Epistemology, Metaphysics, Methodology, and Philosophy of Science. New York: Kluwer Academic Publishers, 1983.

LUGONES, María. Pilgrimages/Peregrinajes: Theorizing Coalition Against Multiple Oppressions. Lanham, MD: Rowman and Littlefield, 2003.

POHLHAUS, Jr., Gaile. "Wrongful Requests and Strategic Refusals to Understand." Feminist Epistemology and Philosophy of Science: Power in Knowledge. Ed. Heidi E. Grasswick. New York: Springer, 2011. 223-240.

QUINE, Willard Van Orman. "On What There Is." Quintessence: Basic Readings from the Philosophy of $W$. V. Quine. Ed. Roger F. Gibson, Jr.. Cambridge, MA: Harvard University Press, 2004. 177192.

SHOTWELL, Alexis. Knowing Otherwise: Race, Gender, and Implicit Understanding. University Park, PA: The Pennsylvania State University Press, 2011. 
-111 -

Anna Mudde

SULLIVAN, Shannon. Revealing Whiteness: The Unconscious Habits of Racial Privilege. Bloomington, IN: Indiana University Press, 2006. 